\title{
Post-fire dynamics of the woody vegetation of a savanna forest (Cerradão) in the Cerrado-Amazon transition zone
}

\author{
Simone Matias Reis ${ }^{*}$, Eddie Lenza ${ }^{2}$, Beatriz Schwantes Marimon², Letícia Gomes ${ }^{3}$, Mônica Forsthofer², \\ Paulo Sérgio Morandi ${ }^{1}$, Ben Hur Marimon Junior ${ }^{2}$, Ted R. Feldpausch ${ }^{4}$ and Fernando Elias ${ }^{2}$
}

Received: October 7, 2014. Accepted: April 23, 2015

\begin{abstract}
Fire can change the species composition, diversity, and structure of savanna vegetation, thus altering growth and mortality rates. Such changes in the woody vegetation of burned savanna forest were evaluated over four years in comparison to unburned savanna forest. All woody plants with a diameter at breast height $>10 \mathrm{~cm}$ were measured in 100 permanent plots. Six months later, 38 of these plots were burned. Three and a half years later, all surviving individuals were re-sampled. Species richness, diversity, and the number of individuals did not change in the burned plots, although they had significantly higher $(p<0.05)$ increases in basal area and mortality rates $\left(5.1 \%\right.$ year $\left.^{-1}\right)$ than the unburned plots $\left(3.0 \%\right.$ year $\left.{ }^{-1}\right)$. Tachigali vulgaris had the greatest post-fire increase in basal area $(53 \%)$. The results indicate that fire alters the dynamics and structure of the savanna forest, excluding the less fire-tolerant species and smaller individuals $(\leq 15 \mathrm{~cm})$. Tachigali vulgaris is a key species for the recovery of savanna forest biomass due to its considerable post-fire gains in basal area, at least over the short term due to its short life cycle. It follows that frequent burning of savanna forest would result in a marked change in the species composition and structure of its woody vegetation.
\end{abstract}

Keywords: conservation, land-use change, mortality, structural and floristic changes, wildfire

\section{Introduction}

Forest and savanna are alternative stable states, maintained by the positive feedback between fire and vegetation (Staver $e t$ al. 2011). Fire affects tropical forests (Cochrane 2003) mainly during drought years (Brando et al. 2014), resulting in increased greenhouse gas emissions (Aragão \& Shimabukuro 2010), and changes in biodiversity (Cochrane 2003). In the savannas, by contrast, fire is an intrinsic and regularly recurring phenomenon (Miranda et al. 2002; Staver et al. 2011). While Brazilian savanna vegetation is fire-adapted (Coutinho 1990; Walter \& Ribeiro 2010), the frequency and intensity of fires can lead to changes in its floristic composition, structure, and vegetation dynamics (Hoffmann 1999; Miranda et al. 2002; Smit et al. 2010). Frequent fires may also reduce the density of woody plant species (Hoffmann 1999; Moreira 2000; Lima et al. 2009), alter growth rates and reproductive success (Frost \& Robertson 1985; Hoffmann 1999), as well as decrease species richness (Coutinho 1990; Ribeiro et al. 2012), due to the exclusion of fire-sensitive species (Moreira 2000).

Forest formations located in the transition zone between Amazon forest and the Brazilian savanna (Cerrado), generally known as transitional forests (Balch et al. 2011; Brando et al. 2014), are less affected by fire (Barlow et al. 2003; Haugaasen et al. 2003) than "core" Amazon forests (Balch et al. 2011). This is due to the presence of less flammable materials (Balch et al. 2011) and tree species typical of the savanna, which are better adapted to fire (Hoffmann et al. 2012). These transitional forests contain patches of savanna forest (known locally as cerradão) which are characterized by the presence of tree species typical of both the forest and the savanna (Ribeiro \& Walter 2008). The savanna forest habitats of central Brazil are relatively vulnerable to fire (Moreira 2000; Hoffmann \& Moreira 2002), and wildfires provoke high mortality rates (Hoffmann \& Moreira 2002) and may affect habitat dynamics. However, the effects of fire on the savanna forests of the transition zone have yet to be studied in detail. This region also corresponds to the "Arc of deforestation" of the southern Amazon basin, where the advance of cattle ranching and agribusiness have resulted in an increase in the effects of wildfires on local forests, represents a serious threat to the natural vegetation (Nogueira et al. 2008; Brando et al. 2014). Wildfires result in an increase in the availability of combustible material,

\footnotetext{
${ }^{1}$ Programa de Pós Graduação em Biodiversidade e Biotecnologia, Rede BIONORTE UNEMAT/UFAM, P.O. Box 08, 78690-000, Nova Xavantina, MT, Brazil

${ }^{2}$ Programa de Pós-Graduação em Ecologia e Conservação, Universidade do Estado de Mato Grosso, P.O. Box 08, 78690-000, Nova Xavantina, MT, Brazil

${ }^{3}$ Programa de Pós-Graduação em Ecologia, Universidade de Brasília, 70919-970, Brasília-DF, Brazil

${ }^{4}$ Geography, College of Life and Environmental Sciences, University of Exeter, EX4 4RJ, United Kingdom

"Corresponding author: simonematiasreis@gmail.com
} 
intensifying the risk of new fires and the complete degradation of the forest (Fearnside 2005; 2006).

Studies of vegetation dynamics allow the monitoring and prediction of transformative processes over time in the structure of communities and populations following wildfires (Harper 1977). This approach can provide important data for the planning of conservation measures in remnant ecosystems (Franczak et al. 2011), as well as increasing basic knowledge of species characteristics (e.g. mortality rates, resilience, resistance), contributing to the success of the restoration of degraded areas. The systematic evaluation of the temporal effects of wildfires can be especially useful for the understanding of the risks of changes in land use for the composition, diversity and structure of transitional savanna forests.

Our aim was to compare temporal differences in the structure, species composition, and the population dynamics of a woody plant community representing a savanna forest ecosystem of the Amazon-Cerrado transition zone in eastern Mato Grosso, Brazil. The study compared the characteristics of sample plots burnt during a wildfire in 2008 with neighboring plots that survived the fire, as well as comparing both types of plot over a four-year period, between 2008 and 2012. We tested the hypothesis that community dynamics differed significantly between burned and unburned savanna forest over the study period due to the alterations caused by wildfires on species composition, diversity, and the structure of savanna vegetation, in particular through modifications of growth and mortality rates (Hoffmann 1999; Miranda et al. 2002; Smit et al. 2010).

\section{Material and methods}

\section{Study area}

The study was conducted in an area of preserved savanna forest in the Bacaba Municipal Park (-52.3507 W and $-14.7006 \mathrm{~S}$, altitude $324 \mathrm{~m}$ ), in the southeastern extreme of the Amazon-Cerrado transition zone in the municipality of Nova Xavantina, Mato Grosso, Brazil. The soil is an acidic (pH 5.0) and dystrophic $\left(\mathrm{Ca}^{2+} 0.4 \mathrm{cmol}_{\mathrm{c}} \mathrm{kg}^{-1}\right)$ yellow oxisol with high levels of exchangeable aluminum $\left(\mathrm{Al}^{3+} 1.3 \mathrm{cmol}_{\mathrm{c}}\right.$ $\mathrm{kg}^{-1}$ ) and medium texture (Marimon-Junior \& Haridasan 2005). The type of regional climate is type Aw in Köppen's classification (Silva et al. 2008), with two well-defined seasons - a cool dry season and a hot rainy season. Mean annual rainfall is $1500 \mathrm{~mm}$ and monthly mean temperature is $25^{\circ} \mathrm{C}$ (Marimon et al. 2010).

\section{Data collection}

In March 2008, 100 permanent and contiguous plots of 10 $\mathrm{m} \times 10 \mathrm{~m}$, with a total area of 1 hectare, were established within the area of the TROBIT (Tropical Biomes in Transition) project. In each plot, all live individuals with diameter at breast height $\left(D B H_{1.30 \mathrm{~m}}\right) \geq 10 \mathrm{~cm}$ were measured, identified, and labeled.
A wildfire passed through the study area in September 2008 , affecting the whole area of 38 of the study plots, but leaving 61 intact. We excluded one partially burned plot from the analyses because only some of the individuals in the plot had been affected by the fire. In January 2012, forty months after the fire, all surviving live woody plants were measured following the original 2008 protocol, including all new recruits that had reached the minimum size criterion for inclusion in the sample.

Botanical samples were collected for species identification and deposited in the NX Herbarium on the Nova Xavantina campus of Mato Grosso State University. The species were identified by specialists and through comparisons with herbarium voucher specimens deposited at the NX Herbarium. The APG III (APG 2009) classification system was used for families and taxon names followed the 2012 List of Species of the Brazilian Flora (in http://floradobrasil.jbrj.gov.br/2012).

\section{Data analysis}

Spatial autocorrelation was assessed by Moran's $I$ index and no spatial dependence was detected among subplots for any of the variables tested (Fig. 1 in supplemental material) (see Eisenlohr 2014 and references therein). Species richness, density and basal area were calculated for each plot and the mean values were compared between years for plots of the same condition (i.e., burned plots in 2008 vs. 2012, and unburned plots in 2008 vs. 2012) using a Repeated Measures Analysis of variance (ANOVA) (Zar 2010). Shannon's diversity index ( $H$ ', in neperian base) was also compared between years for plots of the same condition using Hutcheson's $t$ test (Zar 2010). The homogeneity of variances was verified using Levene's test (Zar 2010). We calculated the percentage increase or decrease in density and basal area for species represented by at least 10 individuals in the burned plots in 2008 (pre-fire) and classified each species as (i) unaffected, (ii) fire sensitive or (iii) fire benefited. Histograms were created to represent the distribution of individuals in $5 \mathrm{~cm}$ classes of diameter. The Kolmogorov-Smirnov (KS) test (Zar 2010) was used to compare the distribution of individuals by diameter class between years (2008 and 2012).

The data on the number of individuals collected in the two surveys (2008 and 2012) were used to calculate: mean annual rates of mortality $\left(\mathrm{M}=\left\{1-\left[\left(\mathrm{N}_{0}-\mathrm{N}_{\mathrm{m}}\right) / \mathrm{N}_{0}\right]^{1 / t}\right\} \times 100\right)$, recruitment $\left(\mathrm{R}=\left[1-\left(1-\mathrm{N}_{\mathrm{r}} / \mathrm{N}_{\mathrm{t}}\right)^{1 / t}\right] \times 100\right)$ (Sheil et al. 1995; 2000), half-life period $\left(\mathrm{T}_{1 / 2}=\mathrm{L}_{\mathrm{n}}(1 / 2) / \operatorname{Ln}\left[\left(\mathrm{N}_{0}-\mathrm{N}_{\mathrm{m}}\right) / \mathrm{N}_{0}\right]^{1 / \mathrm{t}}\right)$, duplication $\left(\mathrm{T}_{2}=\operatorname{Ln}(2) / \operatorname{Ln}\left[\left(\mathrm{N}_{0}+\mathrm{N}_{\mathrm{r}}\right) / \mathrm{N}_{0}\right]^{1 / t}\right)$ (Swaine \& Lieberman 1987), stability $\left(\mathrm{E}=\left(\mathrm{T}_{1 / 2}-\mathrm{T}_{2}\right)\right.$, and turnover $\left(\right.$ Rep $\left.=\left(\mathrm{T}_{1 / 2}+\mathrm{T}_{2}\right) / 2\right)($ Korning \& Balslev 1994), where $t$ is the time between surveys, $N_{0}$ and $N_{t}$ are the initial and final number of individuals, $N_{m}$ and $N_{r}$ are the number of dead individuals and recruits, respectively, and Ln is the natural logarithm of the function. 
Based on the basal area for both types of plot before (March 2008) and about four years after (January 2012) burning, we calculated the mean annual rates of loss $\left(\mathrm{P}=\left\{1-\left[\left(\mathrm{AB}_{0}-\mathrm{AB}_{\mathrm{m}}-\mathrm{AB}_{\mathrm{d}}\right) / \mathrm{AB}_{0}\right]^{1 / t}\right\} \times 100\right)$ or gain $\left(\mathrm{G}=\left\{1-\left[1-\left(\mathrm{AB}_{\mathrm{r}}+\mathrm{AB}_{\mathrm{g}}\right) / \mathrm{AB}_{\mathrm{t}}\right]^{\mathrm{m} / \mathrm{t}}\right\} \times 100\right)$ in basal area (Guimarães et al. 2008), where $A B_{0}$ and $A B_{t}$ are the initial and final basal areas recorded for the live individuals, $A B_{m}$ and $A B_{r}$ are the basal area of the trees dying and being recruited between 2008 and 2012, and $A B_{d}$ and $A B_{g}$ are the decrease and gain in basal area of all other live individuals. Based on their diameter, we calculated the mean annual increase (or decrease) in diameter between 2008 and 2012 of all surviving individuals and compared burned and unburned plots using Analysis of variance (ANOVA) for independent samples (Zar 2010).

The mean annual rates of mortality, recruitment, variation in basal area, half-life and duplication periods, turnover rates and period of stability were calculated for each plot and compared between burned and unburned plots using Analysis of variance (ANOVA) for independent samples (Zar 2010). This test was also used to verify the significance of differences between gains and losses in other parameters. When the data sets did not present homoscedasticity, the Mann-Whitney (U) test was applied (Zar 2010). All analyses were conducted in the R software, version 2.13 (R Development Core Team 2011), with a significance level of $5 \%$ in all cases.

\section{Results}

Some variation was found in species composition between years in both burned and unburned plots, although the difference was more pronounced in the burned ones. Two new species - Alchornea discolor and Cordiera myrciifolia - were found in the unburned plots in 2012. In the burned plots, six species disappeared (Qualea grandiflora, Guapira graciliflora, Byrsonima coccolobifolia, Mezilaurus crassiramea, Alchornea discolor and Andira cujabensis), and three new ones appeared (Machaerium acutifolium, Vochysia haenkeana and Tabebuia aurea) by 2012 (Tab. 1). Despite these changes, neither species richness nor diversity varied significantly between years in either type of plot $(p>0.05)$. In the unburned plots, 47 species were recorded in 2008 , and 49 in 2012, while 43 and 40 species were recorded, respectively, in the burned plots. Diversity $\left(H^{\prime}\right)$ in the unburned plots was 2.94 in 2008 and 2.97 in 2012, and was 3.02 and 2.93 , respectively, in the burned ones.

Table 1. Woody species $\left(\mathrm{DBH}_{1.3 \mathrm{~m}} \geq 10 \mathrm{~cm}\right)$ sampled in a savanna forest (cerradão) in Bacaba Municipal Park, Nova Xavantina (Mato Grosso, Brazil), with the respective density of individuals (ind.ha $\left.{ }^{-1}\right)$, basal area $\left(\mathrm{m}^{2} . \mathrm{ha}^{-1}\right)$ and mean annual increase in $D B H(\mathrm{~cm})$. The species are listed in decreasing order of individual abundance in 2008 (pre-wildfire). USF08 = unburned savanna forest sampled in 2008, USF12 = unburned savanna forest sampled in 2012, BSF08 = burned savanna forest sampled in March 2008 (six months prior to the wildfire), BSF12 = burned savanna forest sampled in January 2012 (40 months after the fire). MAI = Mean annual increase between 2008 and $2012 . \%=$ percentage increase or decrease in density or basal area in species with $\geq 10$ individuals in 2008 ; $\bullet=$ unaffected; $\bullet=$ fire sensitive; ${ }^{*}=$ fire benefited.

\begin{tabular}{|c|c|c|c|c|c|c|c|c|c|c|c|c|c|c|}
\hline \multirow{2}{*}{ Species } & \multicolumn{4}{|c|}{ Absolute Density (ind.ha ${ }^{-1}$ ) } & \multicolumn{8}{|c|}{ Basal Area $\left(\mathrm{m}^{2} \cdot \mathrm{ha}^{-1}\right)$} & \multicolumn{2}{|c|}{ MAI $(D B H \mathrm{~cm})$} \\
\hline & USF08 & USF12 & BSF08 & BSF 12 & $\%$ USF & $\% \mathrm{BSF}$ & USF08 & USF12 & BSF08 & BSF12 & $\%$ USF & \%BSF & USF & BSF \\
\hline Hirtella glandulosa Spreng.• & 147 & 146 & 125 & 127 & -0.7 & 1.6 & 2.71 & 2.85 & 2.83 & 3.05 & 5.2 & 7.8 & 0.14 & 0.19 \\
\hline Tachigali vulgaris L.G.Silva \& H.C.Lima & 56 & 70 & 92 & 92 & 25.0 & 0.0 & 1.34 & 1.29 & 1.82 & 2.79 & -3.7 & 53.3 & 0.67 & 1.14 \\
\hline Myrcia splendens (Sw.) DC.• & 25 & 20 & 53 & 51 & -20.0 & -3.8 & 0.39 & 0.33 & 0.69 & 0.72 & -15.4 & 4.3 & 0.07 & 0.17 \\
\hline Xylopia aromatica (Lam.) Mart. & 56 & 48 & 44 & 19 & -14.3 & -56.8 & 0.76 & 0.67 & 0.67 & 0.35 & -11.8 & -47.8 & 0.17 & 0.10 \\
\hline Emmotum nitens (Benth.) Miers & 32 & 31 & 39 & 35 & -3.1 & -10.3 & 0.94 & 0.83 & 1.04 & 1.05 & -11.7 & 1.0 & 0.19 & 0.33 \\
\hline Eriotheca gracilipes (K.Schum.) A.Robyns & 12 & 11 & 36 & 30 & -8.3 & -16.7 & 0.54 & 0.54 & 0.84 & 0.81 & 0.0 & -3.6 & 0.15 & 0.24 \\
\hline Aspidosperma multiflorum A.DC.* & 14 & 16 & 14 & 22 & 14.3 & 57.1 & 0.17 & 0.21 & 0.20 & 0.30 & 23.5 & 50.0 & 0.16 & 0.22 \\
\hline Pterodon pubescens (Benth.) Benth.• & 5 & 5 & 14 & 14 & -- & 0.0 & 0.15 & 0.18 & 0.29 & 0.32 & -- & 10.3 & 0.43 & 0.20 \\
\hline Luetzelburgia praecox (Harms) Harms $\bullet$ & 3 & 3 & 14 & 14 & -- & 0.0 & 0.04 & 0.04 & 0.18 & 0.18 & -- & 0.0 & 0.06 & 0.28 \\
\hline Tapirira guianensis Aubl. & 36 & 46 & 14 & 5 & 27.8 & -64.3 & 0.76 & 1.03 & 0.20 & 0.08 & 35.5 & -60.0 & 0.45 & 0.58 \\
\hline Aspidosperma subincanum Mart.• & -- & -- & 11 & 11 & -- & 0.0 & -- & -- & 0.13 & 0.17 & -- & 30.8 & -- & 0.36 \\
\hline Buchenavia tomentosa Eichler & 2 & 2 & 11 & 8 & -- & -27.3 & 0.02 & 0.02 & 0.20 & 0.19 & -- & -5.0 & 0.05 & 0.13 \\
\hline Roupala montana Aubl. & 5 & 3 & 11 & 5 & -- & -54.5 & 0.09 & 0.03 & 0.16 & 0.09 & -- & -43.8 & -0.15 & 0.23 \\
\hline Vatairea macrocarpa (Benth.) Ducke & 22 & 26 & 8 & 14 & 18.2 & -- & 0.41 & 0.49 & 0.14 & 0.21 & 19.5 & -- & 0.21 & 0.28 \\
\hline Matayba guianensis Aubl. & 12 & 16 & 8 & 8 & 33.3 & -- & 0.14 & 0.19 & 0.13 & 0.15 & 35.7 & -- & 0.12 & 0.63 \\
\hline Heisteria ovata Benth. & 8 & 8 & 8 & 8 & -- & -- & 0.08 & 0.08 & 0.18 & 0.18 & -- & -- & 0.05 & 0.03 \\
\hline Protium heptaphyllum (Aubl.) Marchand & 7 & 7 & 8 & 8 & -- & -- & 0.08 & 0.09 & 0.09 & 0.10 & -- & -- & 0.32 & 0.26 \\
\hline Terminalia argentea Mart. & 2 & 2 & 8 & 8 & -- & -- & 0.03 & 0.03 & 0.12 & 0.12 & -- & -- & 0.02 & 0.07 \\
\hline Chaetocarpus echinocarpus (Baill.) Ducke & 14 & 20 & 6 & 8 & 42.9 & -- & 0.15 & 0.21 & 0.10 & 0.15 & 40.0 & -- & 0.09 & 0.47 \\
\hline Curatella americana $\mathrm{L}$. & 8 & 5 & 6 & 8 & -- & -- & 0.12 & 0.09 & 0.07 & 0.09 & -- & -- & -0.01 & -0.03 \\
\hline $\begin{array}{l}\text { Pseudobombax longiflorum } \\
\text { (Mart. \& Zucc.) A.Robyns }\end{array}$ & 7 & 8 & 6 & 5 & -- & -- & 0.07 & 0.08 & 0.08 & 0.09 & -- & -- & 0.09 & 0.19 \\
\hline $\begin{array}{l}\text { Guapira graciliflora } \\
\text { (Mart. ex Schmidt) Lundell }\end{array}$ & 6 & 7 & 9 & 5 & -- & -- & 0.18 & 0.10 & 0.08 & 0.05 & -- & -- & 0.29 & 0.07 \\
\hline
\end{tabular}


Table 1. Continuation

\begin{tabular}{|c|c|c|c|c|c|c|c|c|c|c|c|c|c|c|}
\hline \multirow{2}{*}{ Species } & \multicolumn{4}{|c|}{ Absolute Density (ind.ha ${ }^{-1}$ ) } & \multicolumn{8}{|c|}{ Basal Area $\left(\mathrm{m}^{2} \cdot \mathrm{ha}^{-1}\right)$} & \multicolumn{2}{|c|}{$\operatorname{MAI}(D B H \mathrm{~cm})$} \\
\hline & USF08 & USF12 & BSF08 & BSF12 & $\%$ USF & $\%$ BSF & USF08 & USF12 & BSF08 & BSF12 & $\%$ USF & $\%$ BSF & USF & BSF \\
\hline Bowdichia virgilioides Kunth & 3 & 3 & 6 & 5 & -- & -- & 0.11 & 0.10 & 0.05 & 0.05 & -- & -- & -0.03 & 0.00 \\
\hline Dipteryx alata Vogel & 3 & 3 & 6 & 5 & -- & -- & 0.08 & 0.09 & 0.16 & 0.19 & -- & -- & 0.23 & 0.52 \\
\hline Guapira noxia (Netto) Lundell & 3 & 3 & 6 & 5 & -- & -- & 0.03 & 0.02 & 0.10 & 0.09 & -- & -- & -0.39 & -0.22 \\
\hline Platypodium elegans Vogel & -- & -- & 6 & 5 & -- & -- & -- & -- & 0.12 & 0.14 & -- & -- & -- & 0.37 \\
\hline Qualea parviflora Mart. & -- & -- & 6 & 5 & -- & -- & -- & -- & 0.09 & 0.09 & -- & -- & -- & -0.05 \\
\hline Maprounea guianensis Aubl. & 3 & 7 & 6 & 3 & -- & -- & 0.03 & 0.08 & 0.08 & 0.06 & -- & -- & 0.60 & 0.15 \\
\hline Strychnos pseudoquina A.St.-Hil. & 2 & 2 & 6 & 3 & -- & -- & 0.05 & 0.05 & 0.17 & 0.12 & -- & -- & -0.02 & 0.01 \\
\hline Alchornea discolor Poepp. & -- & 3 & 6 & -- & -- & -- & -- & 0.03 & 0.05 & -- & -- & -- & -- & -- \\
\hline Copaifera langsdorffii Desf. & 5 & 5 & 3 & 5 & -- & -- & 0.07 & 0.09 & 0.02 & 0.07 & -- & -- & 0.49 & 0.67 \\
\hline Astronium fraxinifolium Schott & 5 & 5 & 3 & 3 & -- & -- & 0.05 & 0.05 & 0.05 & 0.05 & -- & -- & -0.05 & 0.05 \\
\hline Sorocea klotzschiana Baill. & 3 & 5 & 3 & 3 & -- & -- & 0.03 & 0.06 & 0.05 & 0.06 & -- & -- & 0.41 & 0.52 \\
\hline Hirtella gracilipes (Hook.f.) Prance & 2 & 2 & 3 & 3 & -- & -- & 0.02 & 0.02 & 0.02 & 0.03 & -- & -- & 0.03 & 0.44 \\
\hline Magonia pubescens A.St.-Hil. & 2 & 2 & 3 & 3 & -- & -- & 0.02 & 0.02 & 0.05 & 0.06 & -- & -- & 0.29 & 0.64 \\
\hline Ficus sp. & -- & -- & 3 & 3 & -- & -- & -- & -- & 0.03 & 0.04 & -- & -- & -- & 0.83 \\
\hline Ouratea spectabilis (Mart.) Engl. & -- & -- & 3 & 3 & -- & -- & -- & -- & 0.05 & 0.04 & -- & -- & -- & -0.34 \\
\hline Qualea multiflora Mart. & -- & -- & 3 & 3 & -- & -- & -- & -- & 0.04 & 0.04 & -- & -- & -- & 0.11 \\
\hline Qualea grandiflora Mart. & 5 & 3 & 3 & -- & -- & -- & 0.08 & 0.07 & 0.05 & -- & -- & -- & 0.26 & -- \\
\hline Byrsonima coccolobifolia Kunth & 2 & 2 & 3 & -- & -- & -- & 0.02 & 0.02 & 0.03 & -- & -- & -- & 0.00 & -- \\
\hline Mezilaurus crassiramea (Meisn.) Taub. ex Mez & 2 & 2 & 3 & -- & -- & -- & 0.02 & 0.01 & 0.13 & -- & -- & -- & -0.08 & -- \\
\hline Andira cujabensis Benth. & -- & -- & 3 & -- & -- & -- & -- & -- & 0.02 & -- & -- & -- & -- & -- \\
\hline Vochysia haenkeana Mart. & 5 & 8 & -- & 5 & -- & -- & 0.06 & 0.21 & -- & 0.06 & -- & -- & 0.54 & -- \\
\hline Machaerium acutifolium Vogel & 2 & 2 & -- & 3 & -- & -- & 0.02 & 0.02 & -- & 0.02 & -- & -- & -0.03 & -- \\
\hline $\begin{array}{l}\text { Tabebuia aurea (Silva Manso) Benth. } \\
\text { \& Hook.f. ex S.Moore }\end{array}$ & -- & -- & -- & 3 & -- & -- & -- & -- & -- & 0.02 & -- & -- & -- & -- \\
\hline $\begin{array}{l}\text { Agonandra brasiliensis } \\
\text { Miers ex Benth. \& Hook.f. }\end{array}$ & 8 & 8 & -- & -- & -- & -- & 0.14 & 0.14 & -- & -- & -- & -- & 0.13 & -- \\
\hline Aspidosperma macrocarpon Mart. & 5 & 5 & -- & -- & -- & -- & 0.06 & 0.05 & -- & -- & -- & -- & -0.13 & -- \\
\hline Coccoloba mollis Casar. & 5 & 5 & -- & -- & -- & -- & 0.05 & 0.05 & -- & -- & -- & -- & 0.09 & -- \\
\hline Vochysia rufa Mart. & 3 & 3 & -- & -- & -- & -- & 0.03 & 0.03 & -- & -- & -- & -- & 0.08 & -- \\
\hline Annona coriacea Mart. & 3 & 2 & -- & -- & -- & -- & 0.03 & 0.02 & -- & -- & -- & -- & 0.02 & -- \\
\hline Siparuna guianensis Aubl. & 3 & 2 & -- & -- & -- & -- & 0.04 & 0.02 & -- & -- & -- & -- & 0.10 & -- \\
\hline Diospyros sericea A.DC. & 2 & 3 & -- & -- & -- & -- & 0.04 & 0.07 & -- & -- & -- & -- & 0.83 & -- \\
\hline Antonia ovata Pohl & 2 & 2 & -- & -- & -- & -- & 0.02 & 0.02 & -- & -- & -- & -- & 0.01 & -- \\
\hline Cardiopetalum calophyllum Schltdl. & 2 & 2 & -- & -- & -- & -- & 0.02 & 0.02 & -- & -- & -- & -- & 0.06 & -- \\
\hline $\begin{array}{l}\text { Chaunochiton kappleri (Sagot ex Engl.) } \\
\text { Ducke }\end{array}$ & 2 & 2 & -- & -- & -- & -- & 0.06 & 0.07 & -- & -- & -- & -- & 0.54 & -- \\
\hline $\begin{array}{l}\text { Cordiera myrciifolia (K.Schum.) C.H.Perss. } \\
\text { \& Delprete }\end{array}$ & -- & 2 & -- & -- & -- & -- & -- & 0.01 & -- & -- & -- & -- & -- & -- \\
\hline Total & 563 & 590 & 622 & 573 & & & 10.32 & 10.80 & 11.61 & 12.45 & & & & \\
\hline
\end{tabular}

The absolute density of individuals in the unburned plots increased significantly from 332 trees in 2008 to 360 in $2012(\mathrm{~F}=22.16, p<0.01)$, with a similar increase $(\mathrm{F}=20.94$, $p<0.01)$ in basal area $\left(2008=6.09\right.$ and $2012=6.59 \mathrm{~m}^{2}$.ha-1). In the burned plots, the absolute density of individuals decreased significantly between years -224 trees in 2008 and 212 in $2012(\mathrm{~F}=1.58, p<0.01)$, although basal area increased significantly $(\mathrm{F}=18.59, p<0.01)$, from $4.18 \mathrm{~m}^{2} \cdot \mathrm{ha}^{-1}$ in 2008 to $4.61 \mathrm{~m}^{2}$.ha-1 in 2012. Tachigali vulgaris contributed substantially to this increase in basal area, due to the marked growth in diameter of the surviving individuals (Tab. 1). If this species is excluded from the estimates of basal area, the burned plots would have suffered a net loss in basal area over the four years, rather than a significant gain (Tab. 1). The mean annual increment in basal area related to the presence of $T$. vulgaris was also twice as great in the burned plots $(\mathrm{F}=10.26$, $p<0.01$ ) in comparison with the unburned ones (Tab. 1).

Of the species with the highest densities in the burned plots in 2008, prior to the fire, five were fire sensitive, and there was a notable post-fire reduction in the density and basal area of Roupala montana, Xylopia aromatica and Tapirira guianensis. By contrast, T. guianensis increased in density by $28 \%$ in the unburned plots over the same period of time (Tab. 1). Aspidosperma multiflorum was fire benefited, with density declining by $15 \%$ in the unburned plots, but increasing by $57 \%$ in the burned ones. The other 
six species were unaffected, presenting equal densities before and after the wildfire (Tab. 1). The density of Tachigali vulgaris in the burned plots was stable, but increased by $26 \%$ in the unburned plots between 2008 and 2012 (Tab. 1).

The unburned plots presented a similar distribution of individuals in diameter classes between 2008 and 2012 (KS, $\left.\chi^{2}=0.05, p>0.05\right)$, whereas this parameter varied significantly in the burned plots $\left(\mathrm{KS}, \chi^{2}=0.14, p=0.03\right)$ due to a reduction in the frequency of individuals in the smallest diameter class (10 to $15 \mathrm{~cm}$ ) and an increase in the larger classes (Fig. 1).

The mean basal area of the dead individuals $(0.85$ $\left.\mathrm{m}^{2} \cdot \mathrm{ha}^{-1}\right)$ found in the unburned plots over the four years did not differ from to that of the recruits, at $0.73 \mathrm{~m}^{2} \cdot \mathrm{ha}^{-1}$ $(\mathrm{U}=1.25, p>0.05)$, with the mean annual loss of $3.64 \%$ year ${ }^{1}$ being similar to the gain, which was $3.08 \%$ year ${ }^{-1}(\mathrm{~F}=1.75$, $p>0.05)$. The mean basal area of the dead individuals $\left(0.61 \mathrm{~m}^{2} \cdot \mathrm{ha}^{-1}\right)$ in the burned plots was significantly greater $(\mathrm{U}=6.33, p=0.02)$ than that of the recruits $\left(0.29 \mathrm{~m}^{2} \cdot \mathrm{ha}^{-1}\right)$, although the mean rate of loss of basal area $\left(3.89 \%\right.$ year $\left.^{-1}\right)$ was similar to that of growth $\left(2.10 \%\right.$ year $\left.^{-1}\right)(\mathrm{F}=0.10, p>0.05)$.

In the burned plots, the smallest diameter class presented the greatest loss in basal area and highest mortality rate (Fig. $2 \mathrm{~A}$ ), whereas in the unburned plots, the great loss of basal area and highest mortality rate was recorded in the largest class (Fig. 2A), due to the death of two large trees belonging to the species Tachigali vulgaris and Emmotum nitens. In both areas the highest rate of gain in basal area was observed in the first diameter class, because of the high recruitment rates, $0.24 \mathrm{~m}^{2} \cdot \mathrm{ha}^{-1}$ in the burned plots and $0.58 \mathrm{~m}^{2} \cdot \mathrm{ha}^{-1}$ in the unburned ones, and the gains in the basal area of the surviving individuals, that is, $0.04 \mathrm{~m}^{2} \cdot \mathrm{ha}^{-1}$ in the burned plots, and $0.03 \mathrm{~m}^{2}$.ha-1 in the unburned ones (Fig. 2B).

Most of the mean parameters of vegetation dynamics did not vary significantly between the burned and unburned plots (Tab. 2), except for the mean annual mortality rate and the annual increase in the diameter of surviving individuals, which was significantly lower in the unburned plots (Tab. 2). A $10 \%$ frequency of dead individuals was recorded in the unburned forest, in contrast with $17 \%$ in the burned plots.

\section{Discussion}

The frequency of wildfires in savanna forest has not been documented systematically, and the long-term "equilibrium" condition of this type of vegetation is not known (Henriques 2005; Veenendaal et al. 2014). Savanna forest probably represents a natural transition resulting from
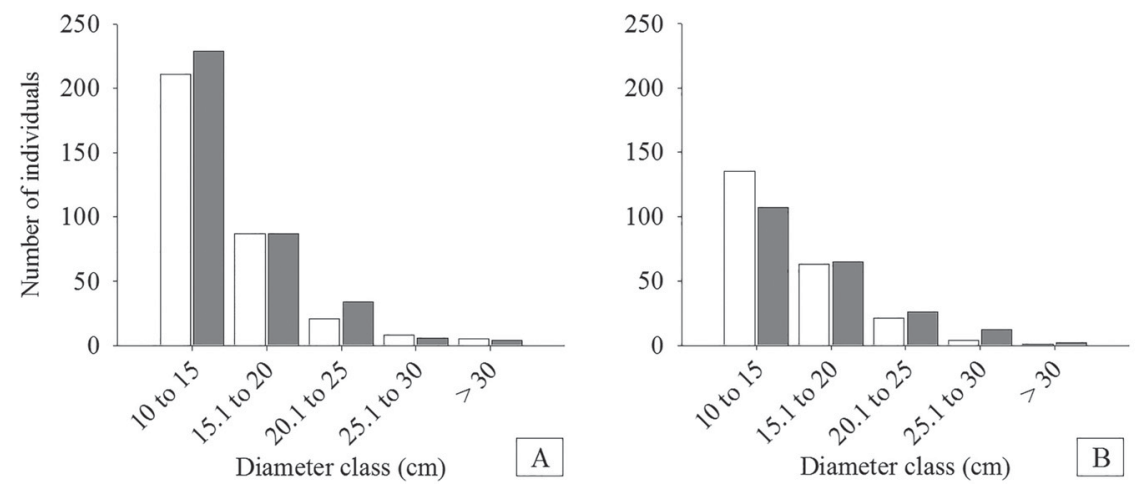

Figure 1. Distribution of woody plants $\left(D B H_{1.3 \mathrm{~m}} \geq 10 \mathrm{~cm}\right.$ ) by diameter class in 2008 ( $\square$ ) and 2012 ( $\square$ ) in the unburned (A) and burned (B) savanna forest (cerradão) plots sampled in the Bacaba Municipal Park, Nova Xavantina (Mato Grosso, Brazil).
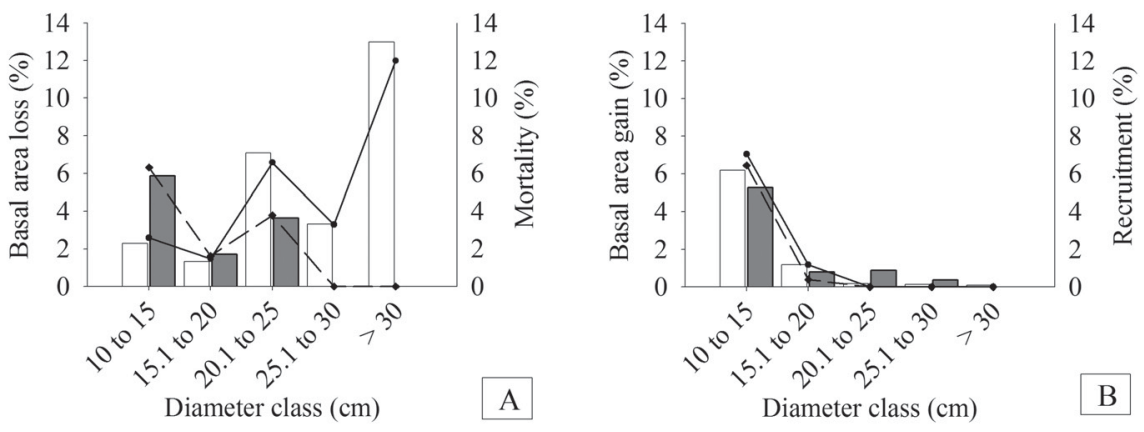

Figure 2. Structural changes between 2008 and 2012 in the woody vegetation $\left(D B H_{1.3 \mathrm{~m}} \geq 10 \mathrm{~cm}\right.$ ) in the unburned ( $\square$ ) and burned ( $\square$ ) savanna forest (cerradão) plots sampled in the Bacaba Municipal Park, Nova Xavantina (Mato Grosso, Brazil). A and B = Annual rates of loss or gain in the basal area and mean annual rate of mortality and recruitment in the unburned (- -) and burned (---) savanna forest plots, respectively. 
Table 2. Mean parameters of the dynamics of the woody vegetation $\left(D B H_{13 \mathrm{~m}} \geq 10 \mathrm{~cm}\right)$ based number of individuals in the unburned (USF $0.61 \mathrm{ha}$ ) and burned (BSF 0.38 ha) savanna forest (cerradão) plots sampled in the Bacaba Municipal Park, Nova Xavantina-MT. USF = unburned savanna forest sampled in March 2008 and January 2012. BSF = burned savanna forest in March 2008 (six months before the wildfire) and in January 2012 (40 months after the fire).

\begin{tabular}{lcccc}
\hline \multicolumn{1}{c}{ Dynamics parameters } & USF $_{\text {61plots }}$ & BSF $_{38 \text { plots }}$ & $\mathrm{F}$ & P \\
\hline Annual mortality rate $\left(\%\right.$ year $\left.^{-1}\right)$ & 2.87 & 5.20 & 4.24 & 0.04 \\
Annual recruitment rate $\left(\%\right.$ year $\left.^{-1}\right)$ & 7.58 & 6.63 & 0.09 & 0.76 \\
Half-life period (years) & 15.55 & 12.48 & 3.12 & 0.08 \\
Duplication period (years) & 14.89 & 16.30 & 0.28 & 0.59 \\
Turnover rate (\% year ${ }^{-1}$ ) & 16.28 & 13.61 & 1.30 & 0.26 \\
Stability (years) & 2.42 & 5.45 & 1.09 & 0.30 \\
Annual increase in diameter $\left(\mathrm{cm}^{\text {years }}{ }^{-1}\right)$ & 0.16 & 0.27 & 3.72 & 0.05 \\
\hline
\end{tabular}

the expansion of forest cover into areas of savanna in the absence of fire (Ratter et al. 1973; Ratter 1992), indicating that the presence of this forest may be related more closely to the water retention capacity of the soil than to its fertility (Marimon-Junior \& Haridasan 2005). In the present study, the occurrence of a wildfire in the savanna forest provided an opportunity to evaluate the responses of individual species and overall changes in community structure, providing potential guidelines for management and conservation.

A number of broad features of the effects of wildfire on the savanna forest were apparent. Firstly, some species were insensitive to fire, while a number of key species benefitted by increasing in diameter (e.g. Tachigali vulgaris) or density (e.g. Aspidosperma multiflorum), or by recruiting new individuals (e.g. Tabebuia aurea). Secondly, there was an expected decrease in density, but an increase in basal area. Thirdly, higher mortality was recorded in the burned plots, in particular in the individuals of smaller size (diameter).

\section{Species richness and diversity}

The occurrence (or absence) of wildfires affects different species in a number of ways. A loss of woody species following wildfires has been observed in a number of different vegetation types, including cerrado stricto sensu (Lima et al. 2009) and savanna forest in the Brazilian Federal District (Moreira 2000) and savannas in North America (Peterson \& Reich 2008). However, burning may favor the appearance of light-demanding species such as Machaerium acutifolium, Tabebuia aurea and Vochysia haenkeana, as observed in the Amazon rainforest (Holdsworth \& Uhl 1997). These changes may result in modifications of the community's silvigenetic cycle (Machado \& Oliveira-Filho 2010), favoring colonization by light-demanding species in the gaps formed in the forest canopy. Of the three species that appeared over the course of the study period, T. aurea is known to be favored by fire due to its high sprouting capacity (Vale \& Lopes 2010). While all three species occur in both burned and unburned plots, the density of $T$. aurea may increase with the frequency of wildfires (Ribeiro et al. 2012).

The high percentage of fire sensitive species $(46 \%$ of those with more than 10 individuals) which decreased in density between 2008 and 2012 indicates that the flora of the savanna forest has a relatively low capacity for recuperation following wildfires in comparison with open savanna formations (Gomes et al. 2014). In other words, wildfires have a greater impact on closed formations in comparison with more open ones, as observed in African savannas (Smit et al. 2010).

An increase in tree species has also been recorded in studies of habitats unaffected by fire - Sanquetta et al. (2000) recorded the addition of a species in a mixed rain forest over a period of three years, while Franczak et al. (2011) subsequently recorded the recruitment of a further seven species within a seven-year period at the same site. Similar results have been recorded in savannas in Brazil (Moreira 2000), Australia (Scott et al. 2012), and Venezuela (San José \& Fariñas 1983). The increase in species richness and diversity in the unburned plots may be related to the opening of gaps following the death of large trees, which favors the appearance of pioneer species such as Alchornea discolor and Cordiera myrciifolia, as observed by Franczak et al. (2011).

\section{Basal area and density}

The increase in basal area recorded in the unburned plots indicates that the community accumulates biomass over time. As the forest formations in the study region - the Amazon-Cerrado transition zone - are encroaching the savanna formations (Marimon et al. 2006), the community will tend to accumulate biomass. An increase in basal area of the savanna forest of the study area would thus be expected (Franczak et al. 2011; Marimon et al. 2014; Oliveira et al. 2014).

While an increase in basal area was observed in the present study, the increase in density in the unburned plots was unexpected because this parameter tends to decrease as a community approaches the typical configuration of a forest formation (Feldpausch et al. 2005). In the present case, then, the savanna forest may still be at an "initial" stage of the silvigenetic cycle, characterized by positive net changes in density, for example (see Marimon et al. 2006; Machado \& Oliveira-Filho 2010; Oliveira et al. 2014). This may also be related to the hyperdynamics typical of the forests of this region (Marimon et al. 2014) and the high density of large pioneer species with a short life cycle, such as Tachigali 
vulgaris. In addition, the comparatively lower mortality rate in relation to recruitment recorded at the study site would lead inevitably to an increase in density. In the absence of fire, then, recruitment occurred at a higher rate, leading to an increase in the density and total biomass of woody plant species, as observed in rain forest by Sanquetta et al. (2000) and in savanna forest by Oliveira et al. (2014).

Even though density decreased in the burned plots, an increase in basal area was observed after burning, in contrast with the pattern observed in other savannas around the world (Hoffmann 1999; Lima et al. 2009; Smit et al. 2010; Scott et al. 2012). This unexpected result is related to the marked increase in the basal area of Tachigali vulgaris $\left(1 \mathrm{~m}^{2} \cdot \mathrm{ha}^{-1}\right)$, which appears to have been a key species for the recovery of the structure and biomass of the savanna forest community over the four-year period following the fire. While the density of this species did not increase after burning, the biomass of the surviving individuals did, maintaining the total biomass of the community. The considerable increase in the biomass of this species was likely due to the reduction in individual density after the fire leading to a decrease in competition for sunlight and nutrients (Lima et al. 2009), which would favor the growth of survivors and accelerate cation leaching from the debris of the burned vegetation, resulting in a significant increase in soil nutrient concentrations, which support plant development (Ivanauskas et al. 2003). In addition, the charcoal formed by the fire acts as a soil conditioner, increasing nutrient availability (Frost \& Robertson 1985; Glaser $e$ t al. 2001). This likely contributed to the increase in the basal area of T. vulgaris, given that this species responds positively to the presence of charcoal in the soil (Souchie et al. 2011). In the absence of this species, then, there would have been a net loss of basal area, demanding further analysis of the effects of wildfires on community dynamics.

\section{Mortality and recruitment}

Fire has a disproportionately greater effect on smaller individuals in comparison with larger ones. A similar pattern has been observed in evergreen seasonal forest in Mato Grosso (Ivanauskas et al. 2003), and in Brazilian and Australian savannas (Hoffmann \& Moreira 2002; Miranda et al. 2002; Lima et al. 2009; Scott et al. 2012). The higher mortality rates recorded in the smaller individuals may be accounted for by the reduced resistance of their thinner bark (Frost \& Robertson 1985; Miranda et al. 2002; Hoffmann et al. 2012).

Recruitment in terms of both the number of individuals and basal area was recorded almost exclusively in the first diameter class in both types of plot. The relatively higher rates of recruitment recorded in this smaller size class in the unburned plots in comparison with the burned ones indicates that fire reduces density and basal area through two processes: (i) increasing mortality rates and (ii) prevention of the recruitment of new individuals into this class. Smaller individuals may either not survive the fire or be incapable of growing to reach higher diameter classes, which will be reflected in a lower recruitment rate (Frost \& Robertson 1985; Miranda et al. 2002). The high proportion of heliophilous species such as Tachigali vulgaris, which had the second highest density, would thus have contributed to the gains in basal area in the smallest diameter classes in the unburned plots, and in the larger classes in the burned plots. The combined effects of fire on individuals of different diameters and the response of key species, such as T. vulgaris, resulted in a shift in the structure of the savanna forest in terms of the girth of its constituent trees.

Recruitment rates did not differ significantly between burned and unburned plots, and were similar to those recorded in unburned tropical rain forests in Costa Rica (Enquist \& Enquist 2011: 3.0\% year ${ }^{-1}$ ) and southeastern Brazil (Gomes et al. 2003: 3.5\% year ${ }^{-1}$ ). Even so, the wildfire led to an increase in the mortality rate in the savanna forest, despite the fact that this habitat was characterized by the presence of number of species more typical of open Cerrado habitats (Ratter et al. 1973; Ribeiro \& Walter 2008) which would have - theoretically - been more tolerant of this type of disturbance (Coutinho 1990; Miranda et al. 2002; Hoffmann et al. 2012). This indicates that species typical of this vegetation type - even those which also occur in the cerrado stricto sensu - have not developed adaptations to the effects of wildfires seen in more typical savanna species, presumably due to the fact that they suffer greatly reduced selection pressure from this phenomenon (Walter \& Ribeiro 2010).

The mortality rate recorded in the burned plots in the present study ( $5 \%$ year $^{-1}$ or $17 \%$ over the four-year period) was lower than those found in Amazon forests. For example, Haugaasen et al. (2003) recorded 36\% mortality one year after a wildfire, while Holdsworth \& Uhl (1997) recorded $44 \%$ mortality after a two-year period, and Barlow et al. (2003) recorded $36 \%$ after one year and $48 \%$ after three years. However, more similar rates have been recorded in the southern Amazon-Cerrado transition zone, such as 5.8\% year ${ }^{-1}$ (Balch et al. 2011) or 19\% after three years (Brando et al. 2014). These lower rates may be related to the increased contribution of savanna species to community composition (Ratter et al. 1973; Ribeiro \& Walter 2008).

The half-life rates found in this study for both types of plot (16.7 and 28.7 years) were much lower than those found in a cerrado stricto sensu, i.e., 58 years by Mews et al. (2011), but more similar to the values recorded in vegetation on rocky outcrops (20 years) in the same region as the present study (Gomes et al. 2014). This indicates that the community studied here is highly dynamic, a pattern reinforced by the high turnover rate of dead individuals ( $\simeq 23$ years at both sites).

The present study provides key data on the response of the poorly-known savanna forest communities to fire. The results indicate that the wildfire altered the species 
composition and structure of the woody vegetation of this habitat and killed trees, with smaller individuals being more affected. The results only partially corroborate the hypothesis tested, however, given the occurrence of an increase in the basal area in the burned plots. In this sense, Tachigali vulgaris appears to be a key savanna forest species for the recuperation of biomass following wildfire disturbance, given the significant investment in biomass of the individuals surviving this disruption. It is nevertheless important to note that this species has a short life cycle (Franczak et al. 2011), and that this "recuperation" of biomass may be no more than a short-term effect, reinforcing the need for further monitoring of the study plots in order to better evaluate the medium- to long-term response. Overall, the results indicated that frequent burn-off of the savanna forest would result in marked modification of the species composition and structure of its woody vegetation, which may be undetectable from biomass estimates alone, at least over the time scale analyzed during the present study.

\section{Acknowledgments}

We are grateful to the research team of the Nova Xavantina Plant Ecology Laboratory for their considerable help in the field, the National Council for Scientific and Technological Development (CNPq), the PELD project "Cerrado-Amazon Forest Transition: ecological and socio-environmental bases for conservation" (process No. 558069/2009-6), PROCAD UnB/UNEMAT (process No. 109/2007), the Biochar project (CNPq No. 575019/2008), the Amazon-Cerrado transition zone Phytogeography project (PPBio No. 457602/2012-0) and the Coordination for the Improvement of Higher Education Personnel (CAPES) for logistic and financial support. T.R. Feldpausch was partly supported by the NERC-funded TROBIT and AMAZONICA projects, and by the Gordon and Betty Moore Foundation. CNPq provided B.H. Marimon-Junior and B.S. Marimon with individual research stipends.

\section{References}

APG - Angiosperm Phylogeny Group. 2009. An update of the angiosperm Phylogeny group classification for the orders and families of flowering plants: APG III. Botanical Journal of the Linnean Society 161: 105-121.

Aragão LE, Shimabukuro YE. 2010. The incidence of fire in Amazonian forests with implications for REDD. Science 328: 1275-1278.

Balch JK, Nepstad DC, Curran LM, et al. 2011. Size, species, and fire behavior predict tree and liana mortality from experimental burns in the Brazilian Amazon. Forest Ecology and Management 261: 68-77.

Barlow J, Peres CA, Logan BO, Haugaasen T. 2003. Large tree mortality and the decline of forest biomass following Amazonian wildfires. Ecology Letters 6: 6-8.

Brando PM, Balch JK, Nepstad DC, et al. 2014. Abrupt increases in Amazonian tree mortality due to drought-fire interactions. Proceedings of the National Academy of Sciences 111: 6347-6352.

Cochrane MA. 2003. Fire science for rainforests. Nature 42: 913-919.

Coutinho LM. 1990. Fire ecology of the Brazilian cerrado. In: Goldammer JG. (ed.) Fire in the tropical biota. Berlin, Springer-Verlag. p. 82-105.
Eisenlohr PV. 2014. Persisting challenges in multiple models: a note on commonly unnoticed issues regarding collinearity and spatial structure of ecological data. Brazilian Journal of Botany 37: 365-371.

Enquist BJ, Enquist CAF. 2011. Long-term change within a Neotropical forest: assessing differential functional and floristic responses to disturbance and drought. Global Change Biology 17: 1408-1424.

Fearnside PM. 2005. Desmatamento na Amazônia brasileira: história, índices e consequências. Megadiversidade 1: 113-123.

Fearnside PM. 2006. Desmatamento na Amazônia: dinâmica, impactos e controle. Acta Amazonica 36: 395-400.

Feldpausch TR, Riha SJ, Fernandes ECM, Wandelli EV. 2005. Development of forest structure and leaf area in secondary forests regenerating on abandoned pastures in central Amazônia. Earth Interactions 9: 1-21.

Franczak DD, Marimon BS, Marimon-Junior BH, Mews HA, Maracahipes L, Oliveira EA. 2011. Changes in the structure of a savanna forest over a six-year period in the Amazon-Cerrado transition, Mato Grosso state, Brazil. Rodriguésia 62: 425-436.

Frost PGH, Robertson F. 1985. The ecological effects of fire in savannas. In: Walker BH. (ed.) Determinants of tropical savannas. IUBS Monograph Series. p. 93-140.

Glaser B, Haumaier L, Guggenberger G, Zech W. 2001. The 'Terra Preta' phenomenon: a model for sustainable agriculture in the humid tropics. Naturwissenschaften 88: 37-41.

Gomes EPC, Mantovani W, Kageyama PY. 2003. Mortality and recruitment of trees in a secondary montane rain forest in southeastern Brazil. Brazilian Journal of Biology 63: 47-60.

Gomes L, Maracahipes L, Marimon BS, et al. 2014. Post-fire recovery of savanna vegetation from rocky outcrops. Flora 209: 201-208.

Guimarães JCC, Van Den Berg E, Castro GC, Machado ELM, OliveiraFilho AT. 2008. Dinâmica do componente arbustivo-arbóreo de uma floresta de galeria aluvial no planalto de Poços de Caldas, MG, Brasil. Revista Brasileira de Botânica 31: 621-632.

Harper JL. 1977. Population biology of plants. Academic Press.

Haugaasen T, Barlow J, Peres CA. 2003. Surface wildfires in central Amazonia: short-term impact on forest structure and carbon loss. Forest Ecology and Management 179: 321-331.

Henriques RPB. 2005. Influência da história, solo e fogo na distribuição e dinâmica das fitofisionomias no bioma do Cerrado. In: Scariot A, Souza-Silva JC, Felfili JM. (eds.) Cerrado: ecologia, biodiversidade e conservação. Brasília, Ministério do Meio Ambiente. p. 73-92.

Hoffmann WA. 1999. Fire and population dynamics of woody plants in a neotropical savana: matrix model projections. Ecology 80: 1354-1369.

Hoffmann WA, Geiger EL, Gotsch SG, et al. 2012. Ecological thresholds at the savanna-forest boundary: how plant traits, resources and fire govern the distribution of tropical biomes. Ecology Letters 15: 759-768.

Hoffmann WA, Moreira AG. 2002. The Role of Fire Population Dynamics of Woody Plants. In: Oliveira PS, Marquis RJ. (eds.) The Cerrados of Brasil. New York, Columbia University Press. p. 159-177.

Holdsworth AR, Uhl C. 1997. Fire in Amazonian selectively logged rain forest and the potential for fire reduction. Ecological Applications 7: 713-725.

Ivanauskas NM, Monteiro R, Rodrigues RR. 2003. Alterations following a fire in a Forest community of Alto Rio Xingu (Mato Grosso, Brazil). Forest Ecology and Management 184: 239-250.

Korning J, Balslev H. 1994. Growth rates and mortality patterns of tropical lowland tree species and the relation to forest structure in Amazonian Ecuador. Journal of Tropical Ecology 10: 151-166.

Lima ES, Lima HS, Ratter JA. 2009. Mudanças pós-fogo na estrutura e composição da vegetação lenhosa, em um cerrado mesotrófico, no período de cinco anos (1997-2002) em Nova Xavantina-MT. Cerne 15: 468-480.

Lista de Espécies da Flora do Brasil. 2012. Jardim Botânico do Rio de Janeiro. http://floradobrasil.jbrj.gov.br/2012/. 20 May 2012.

Machado ELM, Oliveira-Filho AT. 2010. Spatial patterns of tree community dynamics are detectable in a small ( $4 \mathrm{ha}$ ) and disturbed fragment of the Brazilian Atlantic forest. Acta Botanica Brasilica 24: 250-261.

Marimon BS, Felfili JM, Lima ES, Duarte WMG, Marimon-Junior BH. 2010. Environmental determinants for natural regeneration of gallery forest at the Cerrado/Amazonia boundaries in Brazil. Acta Amazonica 40: 107-118. 
Marimon BS, Lima ES, Duarte TG, Chieregatto LC, Ratter JA. 2006. Observations on the vegetation of northeastern Mato Grosso, Brazil. IV. An analysis of the Cerrado-Amazonian Forest ecotone. Edinburgh Journal of Botany 63: 323-341.

Marimon BS, Marimon-Junior BH, Feldpausch TR, et al. 2014. Disequilibrium and hyperdynamic tree turnover at the forest-cerrado transition zone in southern Amazonia. Plant Ecology \& Diversity 7: 281-292.

Marimon-Junior BH, Haridasan M. 2005. Comparação da vegetação arbórea e características edáficas de um cerradão e um cerrado sensu stricto em áreas adjacentes em solos distróficos no leste de Mato Grosso, Brasil. Acta Botanica Brasilica 19: 913-926.

Mews HA, Marimon BS, Maracahipes L, Franczak DD, Marimon-Junior. 2011. Dinâmica da comunidade lenhosa de um cerrado típico na região nordeste do estado de Mato Grosso, Brasil. Biota Neotropica 11: 73-82.

Miranda HM, Bustamante MMC, Miranda AC. 2002. The Fire Factor. In: Oliveira PS, Marquis RJ. (eds.) The Cerrados of Brazil: ecology and natural history of a neotropical savanna. New York, Columbia University Press. p. 51-68.

Moreira AG. 2000. Effects of fire protection on savanna structure in Central Brazil. Jounal of Biogeography 27: 1021-1029.

Nogueira EM, Fearnside PM, Nelson BW, Barbosa RI, Keizer EWH. 2008. Estimates of forest biomass in the Brazilian Amazon: new allometric equations and adjustments to biomass from wood-volume inventories. Forest Ecology and Management 256: 1853-1857.

Oliveira AP, Schiavini I, Vale VS, Lopes SF, Arantes CS, Gusson AE, Prado-Junior JA, Dias-Neto OC. 2014. Mortality, recruitment and growth of the tree communities in three forest formations at the Panga Ecological Station over ten years (1997-2007). Acta Botanica Brasilica 28: 234-248.

Peterson DW, Reich PB. 2008. Fire frequency and tree canopy structure influence plant species diversity in a forest-grassland ecotone. Plant Ecology 194: 5-16.

R Development Core Team. 2011. R: A language and environment for statistical computing. R Foundation for Statistical Computing. Vienna, Austria. ISBN 3-900051-07-0, http://www.R-project.org.

Ratter JA. 1992. Transitions between cerrado and forest vegetation in Brazil. In: Furley PA, Proctor J, Ratter JA. (eds.) Nature and dynamics of Forest-Savanna Boundaries. London, Chapman e Hall London. p. 417-427.

Ratter JA, Richards PW, Argent G, Gifford DR. 1973. Observations on the vegetation of the northeastern Mato Grosso. I. The woody vegetation types of the Xavantina-Cachimbo Expedition area. Philosophical Transactions of the Royal Society of London B 266: 449-492.

Ribeiro JF, Walter BMT. 2008. As principais fitofisionomias do Bioma Cerrado. In: Sano SM, Almeida SP, Ribeiro JF. (eds.) Cerrado: ecologia e flora. Planaltina, Embrapa. p.151-212.
Ribeiro MN, Sanchez M, Pedroni F, Peixoto KS. 2012. Fogo e dinâmica da comunidade lenhosa em cerrado sentido restrito, Barra do Garças, Mato Grosso. Acta Botanica Brasilica 26: 203-217.

San José JJ, Fariñas MR. 1983. Changes in tree density and species composition in a protected Trachypogon savanna, Venezuela. Ecology 64: $447-453$

Sanquetta CR, Pizzatto W, Péllico-Netto S, Figueiredo-Filho A. 2000. Dinâmica da composição florística de um fragmento de floresta ombrófila mista no centro-sul do Paraná. Revista Ciências Exatas e Naturais 2: 77-88.

Scott K, Setterfield S, Douglas M, Parr K, Schatz J, Andersen A. 2012. Does long-term fire exclusion in an Australian tropical savanna result in a biome shift? A test using the reintroduction of fire. Austral Ecology 37: 693-711.

Sheil D, Burslem DFRP, Alder D. 1995. The interpretation and misinterpretation of mortality rate measures. Journal of Ecology 83: 331-333

Sheil D, Jennings S, Savill P. 2000. Long-term permanent plot observations of vegetations dynamics in Budongo, a Ugandan rain Forest. Journal of Tropical Ecology 16: 765-800.

Silva FAM, Assad ED, Evangelista BA. 2008. Caracterização climática do Bioma Cerrado. In: Sano SM, Almeida SP, Ribeiro JF. (eds.) Cerrado: ecologia e flora. Planaltina, Embrapa. p. 69-88.

Smit IP, Asner GP, Govender N, Kennedy-Bowdoin T, Knapp DE, Jacobson J. 2010. Effects of fire on woody vegetation structure in African savanna. Ecological Applications 20: 1865-1875.

Souchie FF, Marimon-Junior BH, Petter FA, Madari BE, Marimon BS, Lenza E. 2011. Carvão pirogênico como condicionante para substrato de mudas de Tachigali vulgaris L.G. Silva \& H.C. Lima. Ciência Florestal 21: 811-821.

Staver AC, Archibald S, Levin SA. 2011. The global extent and determinants of savanna and forest as alternative biome states. Science 334: 230-232.

Swaine MD, Lieberman D. 1987. Note on the calculation of mortality rates. Journal of Tropical Ecology 3: 2-3.

Vale VS, Lopes SF. 2010. Efeitos do fogo na estrutura populacional de quatro espécies de plantas do cerrado. Revista Nordestina de Biologia 19: 45-53.

Veenendaal EM, Torello-Raventos M, Feldpausch TR, et al. 2014. Structural, physiognomic and aboveground biomass variation in savanna-forest transition zones on three continents. How different are co-occurring savanna and forest formations? Biogeosciences 11: 4591-4636.

Walter BMT, Ribeiro JF. 2010. Diversidade fitofisionômica e o papel do fogo no bioma Cerrado. In: Miranda HS. (ed.) Efeitos do regime do fogo sobre a estrutura de comunidades de cerrado: resultados do projeto fogo. Brasília, Ibama. p. 59-76.

Zar JH. 2010. Biostatistical analysis. New Jersey, Prentice Hall. 